\title{
LABORATORY INFECTION WITH TOXOPLASMA
}

\author{
BY \\ B. D. RAWAL \\ From the Bacteriology Department, Sheffield University
}

(RECEIVED FOR PUBLICATION MARCH 27, 1958)

The main object of this paper is, by citing cases of laboratory infection with Toxoplasma, including one personal and hitherto unpublished, to point out the serious risks involved in working with this parasite and to stress the need for care. Another object is to see what can be learnt from these regrettable accidental human experiments about the signs and symptoms to be expected in toxoplasmosis.

\section{Personal Case Report}

In October, 1954, the writer started working with Toxoplasma in Bombay, and it involved the maintenance of the virulent $\mathrm{RH}$ strain by routine passage in mice, the inoculation of fertile eggs, and the performance of the dye test for Toxoplasma antibodies (Sabin and Feldman, 1948). No particular accident, such as a needle prick or a splash, is remembered, but it is likely that at times Toxoplasma got on to the skin, particularly in the performance of the dye test.

Before the work was started the serum was found by the dye test to be free from antibodies to Toxoplasma. It remained so till July 22, 1955. Thereafter it was not tested till the writer fell ill.

About the middle of November, 1955, the patient felt sick and depressed. Afterwards he experienced severe frontal headache accompanied by malaise and muscular pain. On November 18 his temperature rose to $103^{\circ} \mathrm{F}$. and remained elevated for eight days. On the fourth day after the onset of the fever glands in the cervical, axillary, and inguinal regions enlarged and were tender to pressure.

Because of the nature of his work and the signs and symptoms of his illness, toxoplasmosis was suspected and the appropriate serological tests carried out with positive results as shown in Table I.

TABLE I

RESULTS OF SEROLOGICAL TESTS

\begin{tabular}{|c|c|c|c|c|c|}
\hline \multicolumn{4}{|c|}{ Date } & Dye Test & $\begin{array}{l}\text { Complement } \\
\text { Fixation Test }\end{array}$ \\
\hline \multicolumn{4}{|c|}{$\begin{array}{l}\text { July, } 1955 \text { ( } 3 \frac{1}{2} \text { months before illness) } \\
\text { Jan., } 1956 \text { ( } 2 \text { months after onset) }\end{array}$} & \multirow{3}{*}{$\begin{array}{c}<1: 4 \\
1: 256 \\
\text { Between } 1: 256 \\
\text { and } 1: 512 \\
1: 170 \\
1: 271 \\
1: 600\end{array}$} & \multirow{2}{*}{$\begin{aligned} &<1: 4 \\
& 1: 8 \\
& 1: 16\end{aligned}$} \\
\hline Mar., 1956 ( 4 & , , & & , ) & & \\
\hline $\begin{array}{l}\text { Jan., } 1957 \text { (14 } \\
\text { April, } 1957(17 \\
\text { May, } 1957(18\end{array}$ & ,', & ,", & $\begin{array}{l},, \quad) \\
,, \quad)\end{array}$ & & $\begin{aligned}<1: 4 \\
1: 20 \\
1: 40\end{aligned}$ \\
\hline
\end{tabular}

Four months after the onset of illness the patient was given an 11-day course of treatment with $12.5 \mathrm{mg}$. "daraprim" daily and $6 \mathrm{~g}$. sulphadiazine on the first day, followed by a daily dose of $4 \mathrm{~g}$. Within six days of the start of the treatment the headache, which had persisted intermittently, and malaise disappeared. The glands remained enlarged and were, indeed, still enlarged in August, 1957.

\section{Discussion}

From the frequency with which Toxoplasma antibodies are found in the general population it is obvious that man can be readily infected, though strangely little is known of how this comes about. It is, therefore, not surprising that people who handle toxoplasms in the laboratory sometimes develop toxoplasmosis. Indeed, it is strange that this does not happen even more frequently. Perhaps the explanation may be that many people already have antibodies to Toxoplasma, due to natural subclinical infection, before they start to work with the organism. It is certainly striking that of the laboratory workers, whose cases are summarized in Table II, all except two were known to have been previously devoid of antibody. In one patient only (Case 17) was antibody known to have been previously present (dye test $1: 64)$. This patient, in contrast to patient 10 who also squirted Toxoplasma-containing peritoneal exudate into the eye, had only a local manifestation, conjunctivitis. The dye test titre fell from $1: 256$ to the previous level of $1: 64$ in a very short period of three weeks. In most cases antibodies rose to high titres. In six of the patients they accompanied the isolation of the parasite and point to the specificity of the antibody tests. Of course, it does not follow that infection will lead to illness. H. E. (Case 6) developed high titre antibodies after he was bitten by an infected rabbit, but he was not ill. A. A. van S. (Case 18) had enlarged glands from which toxoplasms were isolated, but was afebrile and did not feel ill. E. H. (Case 14) had tonsillitis and salpingitis, but these were regarded as coincidental. There was only 
one fatality in the reported cases (V.F., Case 3). In the other cases the duration of the illness varied from seven days to four months.

The commonest signs and symptoms were headache and malaise (nine cases) and lymphadenopathy (eight cases). In six cases a rash was reported. Three had encephalitic signs and two myocarditis. Two patients, in addition to the two who squirted Toxoplasma-containing material in their eyes, developed conjunctivitis.

In many cases the mode of infection was unknown. Four, however (Cases 1, 8, 16, and 18), were due to a needle prick. Cases 10 and 17 were due to a splash on the face and Case 4 may well have been due to a similar cause. Case 2 was thought to have contracted the illness in pipetting.

The cases in which the actual date of infection was known afford an excellent opportunity of assessing the incubation period. This varied from three days (two cases of splashes in the eye) to three to nine days (needle pricks).

Following the indications given by the therapeutic trials on experimental animals of Sabin and Warren (1942) six of the patients (Cases 1, 2, 3, $8,10,12)$ were treated with sulphonamides. Later patients (Cases $5,15,16)$ were given a combination of a sulphonamide and "daraprim" as first suggested by the work of Eyles and Coleman (1955). There are not enough cases to assess the value of therapy. All that can be said is that Case 8 was free from fever five days after the start of sulphonamide treatment ; Case 3, on the other hand, died in spite of it. Cases 5 and 15 improved after treatment with sulphonamide and "daraprim." Case 16 was free of fever 36 hours after the start of treatment. Cases 11 and 13 were treated with aureomycin. Eyles (1956) reports that enormous doses of this drug, much larger than can be attained in man, are required to produce a favourable result in infected mice. It was used in addition to sulphadiazine in the patient in Case 3, who died, and also unsuccess- fully in the case reported by Kass, Andrus, Adams, Turner, and Feldman (1952).

Three morals can be drawn. First, as with all dangerous organisms, great care should be taken to avoid contamination. A particular risk, and one likely to increase as more laboratories do it, is found in the performance of the dye test (Sabin and Feldman, 1948). Second, as far as possible, only persons who already have Toxoplasma antibodies should be employed on this work. Third, attention should be directed to the development of an effective vaccine for the protection of laboratory workers.

\section{Summary}

The writer reports the course of his own laboratory infection with Toxoplasma and reviews 17 others.

Headache, malaise, and lymphadenopathy were the commonest symptoms and signs.

The need for care when working with Toxoplasma is stressed.

\section{REFERENCES}

Alm, L. (1949). Personal communication to Dr. Eyles. Beverley, J. K. A., Skipper, E., and Marshall, S. C. (1955). Brit. med.J., 1, 577.

Brown, J., and Jacobs, L. (1956). Ann. intern. Med., 44, 565.

Eyles, D. E. (1956). Ann. N.Y. Acad. Sci., 64, 252.

- and Coleman, N. (1955). Antibiot and Chemother., 5, 529.

Hormann, J. (1955). Z. ges. inn. Med., 10, 150.

Kass, E. H., Andrus, S. B., Adams, R. D., Turner, F. C., and Feldman, H. A. (1952). Arch. intern. Med., 89, 759.

Mohr, W. (1953). Die Toxoplasmose. Vortrage der Toxoplasmose Besprechung von 21 und 22 März, 1953, im Hamburger Tropeninstitut, pp. 37 and 38 . Banascheuski, Munich.

stitut, pp. 37 and 38 . Banascheuski, Munich.
Sabin, A. B. (1950). Personal communication to Dr. Eyles.

and Feldman, H. A. (1948). Science, 108, 660.

and Warren, J. (1942). Proc. Soc. exp. Biol. (N.Y.), 51, 19. Eichenwald, H., Feldman, H. A., and Jacobs, L. (1952). J. Amer. med. Ass., 150,1063 .

Sexton, R. C., Eyles, D. E., and Dillman, R. E. (1953). Amer. J. Med., 14, 366.

Soestbergen, A. A. van (1957). Ned. T. Geneesk., 101, 1649.

Straub, W. (1955). "Toxoplasmose des Auges." Bibl. ophthal. (Basel), 41, cited by Thalhammer, O. (1957) in Die Toxoplasmose bei Mensch und Tier, p. 213. Wilhelm Maudrich, Vienna.

Ström, J. (1951). Acta med. Scand., 139, 244.

Thalhammer, O. (1954). Ost. Z. Kinderheilk., 10, 316.

Wettingfield, R. F., Rowe, J., and Eyles, D. E. (1956). Ann. intern. Med. 44, 557.

Wright, W. H. (1957). Amer. J. clin. Path., 28, 1. 